EJEM

Econ.J.Emerg.Mark.

\section{Economic Journal of Emerging Markets}

Available athttp://journal.uii.ac.id/index.php/jep

\title{
Financial development and performance of palm oil industry in Malaysia
}

\author{
Syajarul Imna Mohd Amin ${ }^{1}$, Aisyah Abdul-Rahman ${ }^{1}$, Hawati Janor ${ }^{1 *}$, \\ Abdullah Khairi Mohd Asri ${ }^{1}$, Darmawati Muchtar ${ }^{2}$
}

${ }^{1}$ Center for Sustainable and Inclusive Development, Faculty of Economics and Management,

Universiti Kebangsaan Malaysia, Malaysia

${ }^{2}$ Faculty of Economics and Business, Universitas Malikussaleh, Aceh, Indonesia.

*Corresponding author: hawati@ukm.edu.my

\begin{tabular}{l} 
Article Info \\
\hline Article history: \\
Received : 13 September 2019 \\
Accepted : 3 October 2019 \\
Published : 15 October 2019 \\
\hline
\end{tabular}

Keywords:

Financial development, financegrowth nexus, Malaysia palm oil industry, ARDL

\section{JEL Classification: G10}

DOI: $10.20885 /$ ejem.vol11.iss1.art2

\begin{abstract}
The finance-growth nexus is gaining credence among researchers. Growing research interest in developing evidences for different economic sectors has ignited this study to examine the topic in the agricultural sector for Malaysia. The analysis focuses on the palm oil industry using data for the period 1981 to 2017 using the Autoregressive Distributed Lagged (ARDL-bounds) approach. Financial development measures financial depth, accessibility, efficiency, and stability. Other variables include production factors such as land, labor, and capital. Findings/Originality: The findings show that the depth of the financial market has a positive impact on palm oil industry performance both in the short run and long run, though the depth of the financial institutions only takes effect in the long run. Meanwhile the financial accessibility, efficiency, and stability have no significant effect on the productivity of the industry. It implies that the equity market development is more relevant to affect the palm oil industry compared to credit market development.
\end{abstract}

\section{Introduction}

Southeast Asian countries have undergone significant structural changes in many of its economic activities. According to the report by OECD-FAO (2017), most of the countries in this region have experienced strong growth in Gross Domestic Product (GDP) with average growth close to $5 \%$ per year over the period 2000-2016. Continuous growth is also observed in the regional population which is close to $1.3 \%$ per year over the same period. In line with the growth, Southeast Asia has also made remarkable progress in terms of improving food security. However significant issues on food security still a big concern due to varying levels of development among countries. This concern over food security is highly associated with agriculture development especially in developing countries. This is clearly reflected in the new Sustainable Development Goals (SDGs) which include a significant number of interconnected objectives related to agriculture and food. As pointed out by Brooks (2016), SDG 1 focuses on poverty reduction, where agriculture and food have a key role to play; and also SDG 2 which focuses explicitly on food in quest of "end hunger, achieve food security and improved nutrition and promote sustainable agriculture".

Improving performance in agricultural productivity has played a crucial role for the growth in agricultural output. For the producers, striving factors for the growth are indeed of key importance which is very much relevant to Malaysia. Being one of the countries in Southeast Asia, Malaysia is one of the world's largest agricultural producers in palm oil production besides 
Indonesia. Malaysian production is placed second after Indonesia in the global production of palm oil in 2016, with 17.32 million MT and 31.80 million MT respectively (MPOB, 2017; United Plantation, 2016). The palm oil industry is one of the 12 National Key Economic Areas (NKEAs) which will lead Malaysia towards attaining the high-income nation status in 2020. The industry serves as one of the main source of income among the poor, especially for those living in a rural area. It has been reported that the industry has provided direct employment of 610,000 people including 177, 000 smallholders (ETP, 2012). Thus, the palm oil industry carries a critical role; not only to fulfill the growing global market demand for oils and fats and achieving the interconnected objectives of the SDGs but also to alleviate poverty and promote national economic development. Hence, determining forces that could influence palm oil productivity is a major concern for this country.

Previous literature has shown that agriculture performance is influenced by several forces. Some studies show that agricultural growth is effected by ownership, methods of farming, irrigation facilities; land quality and technical efficiency (Iqbal, Ahmad, \& Abbas, 2003); farmers' managerial skills (Jan \& Khan, 2012); and technology and inputs (Iqbal et al., 2003; Jan \& Khan, 2012). These evidences are based on data from Pakistan. In the case of the European Union and Romania in 2003-2005, Campos, Jaklic, and Juvancic (2010) showed that good structural conditions for agriculture, developed market infrastructure, capital (inputs, investments), economic stability and favorable demographic trends are important to promote the growth of agriculture. Burja (2012) added that agricultural performances between areas in Romania vary due to the labor force and capital. In regards to structural change in different sectors, Stijepic (2017) provides empirical evidence regarding the adequacy of the (aggregate) Cobb-Douglas production function (CDFPs) in the multi-sector study. One of the arguments raised was labor-income share and capital intensity differs across sectors. By using an axiomatic/geometrical approach in the services and agriculture sector, it is shown that sector-level CDPFs are not consistent with standard theory axioms and long-run stylized facts of sector and aggregate dynamics, hence can be regarded as an empirical rejection of the CDPF at a sector level. In other studies also in the agriculture sector, Brenes Muñoz, Lakner, \& Brümmer (2012) highlighted several significant farm-specific factors including farm size, livestock intensity, subsidies and share of grassland area. Existing studies focusing on palm oil industry also found several common factors explaining agricultural performance (price, production, export) including its substitutes commodities (Bergmann, O'Connor, \& Thümmel, 2016; Chuangchid, Wiboonpongse, Sriboonchitta, \& Chaiboonsri, 2012; Nazlioglu \& Soytas, 2012), farm structure (i.e. size, ownership) (Asari et al., 2011; Nuryartono, Pasaribu, \& Panggabean, 2016; Ramasamy, Ong, \& Yeung, 2005) cost of inputs (Nuryartono et al., 2016; Olagunju, 2008), and climate change (Ayat, Ramli, \& Faizah, 2012).

Apart from the above factors, the financial sector has played a significant role to promote palm oil sustainability by providing financial resources to rural farmers and agro-enterprises. Malaysia has developed several financial services like microfinance and special loans for farmers as well as small- and medium-scale enterprises. The main providers of agricultural credit in Malaysia include commercial banks, development financial institutions (e.g. Bank Simpanan Nasional, Agrobank, and SME bank) and microfinance institutions (e.g. Amanah Ikhtiar Malaysia, Yayasan Usaha Maju, and TEKUN). As of June 2016, the total loans outstanding for primary agriculture account for RM 36.7 billion, 2.5\% share of total loans disbursed to small and medium enterprises (Ministry of Finance Malaysia, 2017). To date, the emergence of the Fourth Industrial Revolution (4IR) and Fintech via digital platforms have broken down the barriers of traditional banking activities by reducing cost and improving efficiencies. For instance, the shift from banking branches to ATM and then to online banking has made it possible to outreach clients who previously deprived of banking facilities. Thus, not only that digital finance enhances financial inclusion, but it also bridging the financing gap, particularly rural dwellers like farmers. It 
is noteworthy that the impact of 4IR on the role of financial development towards the seeking of the objectives of the SDGs has linked to the future of the palm oil industry. This has brought the attention within the policy circles on the issue of financial development in affecting the agricultural sector, especially on the growth of palm oil production in Malaysia.

In general, financial development refers to the enhancement in five financial functions qualities: providing informational efficiency regarding potential investments and facilitate capital allocation; monitoring market players and exerting market discipline (i.e. corporate governance); facilitating activities such as trade, diversification, and risk management; mobilizing and pooling funds; and expediting the exchange of goods, services and financial securities (Levine, 1997, 2005). Therefore, these qualities mark the difference between the levels of financial development of each country. Empirical evidence shows that financial development contributes directly to economic growth and indirectly toward poverty alleviation (Demirgüç-Kunt \& Levine, 2008; Hannig \& Jansen, 2010) given its capacity to improve efficient delivery services, to provide saving and loan opportunities, and capital among the poor (Ahmed, 2006). In agriculture, access to finance is crucial for rural farmers and agro-enterprises to finance the purchase of material inputs (i.e. fertilizers, seedling, harvesting, and pesticides), machinery, modern technology, transportation of equipment and outputs, and working capital management. In the era of digital economy, the modern banking services such as internet and mobile banking has further facilitated high-speed transactions like transfers and remittance, accounts update, and information on business and investment opportunities (Harangus, 2009). Apart from that, financial markets (for instance derivative on the commodity market and stock market) also play significant roles in the agriculture sector by providing information to investors for investment and trading activities, facilitating takeovers and compensating managers for improvement in corporate control and resource allocation (Beck, Demirgüç-Kunt, \& Levine, 2010). The need for finance facilities, thus, is very critical for the very improvement of the value chain production of the agricultural sector.

In regards to the theoretical aspect, the issue of finance-growth nexus or the 'supplyleading view' has its long tradition. It is based on finance-led growth theory, dating back to Schumpeter (1911) and has since established in more recent papers (e.g. Bauer, 1990; King \& Levine, 1993a, 1993b; Rajan \& Zingales, 1998). Schumpeter (1911) emphasized that the banking system plays a pivotal role in facilitating innovation and productive investment by entrepreneurs, thus fostering economic growth. Robinson (1952) later claimed that it was economic activities that create the demand for an array of financial services to which the financial system would respond. This issue has since extended in numerous studies using several approaches in different market samples. For instance, in support of finance-led growth hypothesis, empirical evidence is found in India (Hussain \& Chakraborty, 2012), Asian countries (Hsueh, Hu, \& $\mathrm{Tu}, 2013$ ), Pakistan (Gokmenoglu, Amin, \& Taspinar, 2015) and MENA regions (Omri, Daly, Rault, \& Chaibi, 2015). On the other hand, several studies provide consistent findings with the growth-led finance hypothesis (Odhiambo, 2010; Rachdi \& Mbarek, 2011; Simwaka, Ligoya, Kabango, \& Chikonda, 2012). Recent focus has been on the implication of finance-growth relationships within the agricultural sector. However, the existing findings provide inconclusive evidence, indicating positive relationship between financial development and agricultural growth (among others (Devi, 2012; Duy, 2012; Ibrahim \& Bauer, 2013; Sandip, Kumar, \& Mollika, 2015) both in the short and long run (Chisasa \& Makina, 2015; Shahbaz, Shabbir, \& Sabihuddin, 2013); and insignificant finance-agriculture growth relationship (Izhar \& Tariq, 2009; Oliynyk, 2017).

Another strand of literature on the link between financial and productivity highlights the role of credit. The studies such as McKinnon (1973) and Shaw (1973) argue that bank credits help firm employs more workers, have higher investment opportunities and thus growth. Their argument is based on the Mckinnon-Shaw paradigm which postulates that finance barriers such as interest rate ceiling and high reserve requirement may hinder financial deepening and investment 
activities and hence have negative impact on economic growth. The findings of Ibrahim \& Bauer (2013) indicate that farmers with access to micro-credit in Sudan make more profits than those who devoid of such facilities. Similarly, a survey by Dong, Jing, and Featherstone (2010) found that productivity and income of the leveraged farmers are higher than the credit-constrained farmers in China. The authors further added that agricultural productivity in the country can be increased by $31.6 \%$ with the removal of a credit-constrained situation. Toby and Peterside (2014) examined the role of finance on the agriculture and manufacturing sector in Nigeria and found that agriculture credit lagged behind the credit-to-manufacturing sector. The results also show a significantly weak explanatory power of finance on the contribution of agriculture to GDP. In another related study, a negative association of finance -productivity linkage through credit access is documented by Aghion, Bergeaud, Cette, Lecat, and Maghin (2018). While existing literature argues that better credit access should have an unambiguously positive effect on economic growth especially on innovation-based growth (King \& Levine, 1993a; Levine, 1997; Rajan \& Zingales, 1998), Aghion et al. (2018) provide evidence to support that better credit access allows less efficient incumbent firms to remain longer on the market, thereby discouraging entry of new and potentially more efficient innovators. This argument is also related to the effect of credit access on credit risk and asset quality (Chen, Feng, \& Wang, 2018).

Some other studies relate the benefits of credit on technology advancement that consequently improve agriculture productivity. For instance, Muftau (2003) argues that loan provides incentives for agro-enterprises to adopt new technologies in expanding and modernizing all activities across the production chain. Devi (2012) found that there was an enormous increase in the usage of modern seeds, modernized inputs, fertilizers and pesticides after receiving the agricultural credit, which increased yield per acre and thus the income of farmers in India. Further observation indicates the impact of agricultural credit is more significant in non and semi-irrigated villages than the irrigated villages. Bashir, Mehmood, and Hassan (2010) found that agricultural credit facilitates the transformation of agriculture and increase the participation of farmers. Other studies investigate the impact of agricultural finance on the efficiency level of the agricultural sector. Based on Stochastic Frontier Production Analysis (SFA), Ayaz and Hussain (2011) observe that the technical efficiency of farmers in Pakistan is more affected by credit than other factors like farming experience, education, herd size and number of cultivation practices. Similar results are evidenced in the Mekong Delta region of Pakistan, showing the positive impact of access to finance (and two other factors: education level and farm technology) on technical efficiency and rice yield (Duy, 2012). A similar positive relationship is also documented between finance and farm productivity in Pakistan (Rahman, Hussain, \& Taqi, 2014), Nigeria (Nosiru, 2010; Obilor, 2013) and Bangladesh (Sandip et al., 2015). However, some other studies found insignificant finance-agriculture growth relationships during the post-reform period in India (Izhar \& Tariq, 2009), which could be related to regulations governing the operations of the economy, and in Ukraine (Oliynyk, 2017).

Shahbaz et al. (2013) extended previous studies by examining the long-run relationship between financial development and agricultural growth in Pakistan (1971-2011) using several econometric approaches (i.e. ARDL, VECM, and IAA). The findings highlight three points: 1) there exist long-run relationships between all variables i.e. agricultural growth, financial development, capital, and labor) and 2) agricultural growth is positively related to financial growth, capital, and labor; and 3) finance-agricultural growth has a bi-causal relationship. On the same note, by employing Error Correction Modelling (ECM) method, Chisasa and Makina (2015) found one-way causality from: credit to agricultural output growth; agricultural output to capital formation and labor; capital formation to credit and labor; and a bi-directional causality between credit and labor both in short and long run. Interestingly, Hye and Wizarat (2011) developed a financial liberalization index and evaluate the impact on agricultural growth in Pakistan and found 
a positive relationship, both in the short and long run. They further evidence a positive short-run impact of interest rates on agricultural growth and negative effect in the long run.

Although the role of finance has gained much interest in the agricultural sector, existing studies examining the issue in the palm oil industry are lacking. The present research attempts to fill the gaps by establishing evidence on the finance-growth relationship in the palm oil industry, particularly in Malaysia. We aim to bridge the gap by providing evidence on the financeagricultural growth relationship exploring the causality relationship both in the short and long run. In doing so, this study utilizes four stages of empirical approaches including the ARDL testing techniques. We use four financial development indicators, as suggested by Cihak, Demirguc-Kunt, Feyen, and Levine (2012), including financial depth (i.e. agricultural credit); access to financial services (i.e. bank branches); efficiency (i.e. bank lending-deposit spread); and financial stability (i.e. bank credit-to-deposit). The findings of the study will furnish the policymakers with relevant information regarding the issues of this sector which helps them prioritize the financial system development and earmark necessary resources accordingly. This, in turn, helps to realize the long-term economic growth of the palm oil sector in Malaysia.

Based on the above discussion in particular on the proxy and measurements involved, the objective is this paper is to examine the impact of financial development (as indicated by five measures: financial depth, access to financial services, efficiency, financial stability and financial technology) on the productivity of palm oil industry in Malaysia.

\section{Methods}

This study covers the period from 1981 to 2017 using annual time series data. We retrieve palm oil and financial development data from the Datastream and World Bank database, respectively.

In determining the impact of financial development on palm oil production, we develop our research framework based on the Cobb-Douglas input-output productivity model (1928). The traditional agricultural production model assumes that the output responds to the changes in levels of three inputs of production namely capital, labor, and land (Solow, 1997). We modify the three-factor agricultural production by including the financial development variable as an additional input. The palm oil production function can be specified as:

$\mathrm{PO}_{\mathrm{t}}=\alpha_{\mathrm{t}}+\beta_{1}$ Labor $_{\mathrm{t}}+\beta_{2}$ Land $_{\mathrm{t}}+\beta_{3} \mathrm{Cap}_{\mathrm{t}}+\varepsilon_{\mathrm{i}}$

where PO refers to palm oil production, Labor is the number of a paid employee, Land refers to land area, and Cap is fixed assets. $\varepsilon$ is the residual showing the effect of financial development. $\beta$ denotes the marginal impacts of each inputs, following the assumption of constant returns to scale. After decomposition of the residual term, the estimated model is as follows:

$\ln \mathrm{PO}_{\mathrm{t}}=\alpha_{\mathrm{t}}+\beta_{1} \operatorname{lnLabor}_{\mathrm{t}}+\beta_{2} \ln \operatorname{Land}_{\mathrm{t}}+\beta_{3} \operatorname{lnCap} \mathrm{t}+\beta_{4} \ln \mathrm{Fdev}_{\mathrm{t}}+\mu_{\mathrm{i}}$

where $\ln$ is the natural $\log$ of concerned variable and $\mu$ is the residual term. Fdev is financial development dimensions based on Cihak et al. (2012), which are financial depth (private sector credit, stock trade to GDP); access to financial services (bank branches); efficiency (bank lendingdeposit spread); financial stability (non-performing loan-to-gross loan).

We convert all series into natural logarithms since the log-linear specification provides reliable and efficient results (Bowers \& Pierce, 1975; Box \& Cox, 1964). Except for financial depth, other financial development alternatives data are only available starting from 1996 to 2017. We employ the ARDL modeling technique to estimate both the long-run and short-run relationships between palm oil production, labor, land, capital, and financial development. The estimation procedures involve the unit root test, the bounds cointegration test and, the long-run and short-run ARDL tests. 


\section{Unit Root Test}

The presence of unit root in time series data implies non-stationarity. It shows that the series under consideration has no long-term deterministic trend and the variance is time-dependent. If a series has a unit root problem, then differencing of the series will result in stationary. The unit root test is the precondition for time series data, which is to be stationary before conducting cointegration tests. Although the ARDL model can accommodate variables that are integrated at $\mathrm{I}(0)$ or $\mathrm{I}(1)$, the unit root test is necessary to avoid the presence of unit root problem in $\mathrm{I}(2)$. It is carried out using the Augmented Dickey-Fuller (ADF) test, the most superior stationarity test considering its wide application in academic research. The model is estimated with both a constant and a time trend so that it is not restricted. For a given variable, we estimate the ADF test using the following model:

$$
\Delta \Upsilon_{\mathrm{t}}=\omega_{0}+\omega_{\mathrm{i}} \mathrm{t}+(\varrho-1) \Upsilon_{\mathrm{t}-1}+\sum_{i=2}^{k} \varpi_{\mathrm{i}} \Delta \Upsilon_{\mathrm{t}-\mathrm{i}+1}+\varepsilon_{\mathrm{t}}
$$

Where $\Delta$ is a change in $Y_{t}$ or first difference operator, $t$ is the trend factor, $\varepsilon_{t}$ is a white noise residual, $\mathrm{k}$ is the lagged values of $\Delta \mathrm{Y}_{\mathrm{t}}$. The number of lagged difference terms is determined empirically to include enough terms so that the residual is serially uncorrelated. For a given series, if the estimate of $\varrho \geq 0$, the series is stationary. In other terms, if the ADF value is greater than its critical values, it shows that the underlying series is stationary and, vice versa. Since the objective is to test the long-run and short-run relationship between variables, it is a precondition of the cointegration test for the data series to be integrated of the order of 1 , that is, I(1).

\section{Bounds test and Autoregressive Distributed Lag Framework (ARDL)}

We employ the bounds testing approach within the ARDL framework developed by Pesaran, Shin, and Smith (2001) to ascertains that the series has long term information (i.e. there is a longrun relationship between variables). The bounds test is more superior than the other cointegration testing alternatives such as Engle \& Granger (1987)'s two-step residual-based procedure and the Johansen (1988, 1995)'s and Johansen and Juselius (1990)'s system-based reduced rank regression approach is threefold (Narayan \& Narayan, 2004). First, it fits a series irrespective of whether the underlying regressors are purely $\mathrm{I}(0)$, purely $\mathrm{I}(1)$ or a combination of both. Thus, the pre-testing of the order of integration is not a requirement ${ }^{1}$. Second, the unrestricted error correction model (UECM) has better statistical properties than the EngleGranger method because it does not push the short-run dynamics into the residual terms (Banerjee, Dolado, \& Mestre, 1998; Banerjee, Galbraith, \& Hendry, 1993). The UECM integrates the short-run dynamics with the long-run equilibrium without losing any long run information. Third, it fits for a small sample unit, as in the case of the present study.

The error correction representations of the ARDL specification model for Eq. (2) are given by:

$$
\begin{aligned}
\Delta \mathrm{PO}_{\mathrm{t}}= & \alpha_{0}+\sum_{i=1}^{p} \beta_{1} \Delta \mathrm{PO}_{\mathrm{t}-\mathrm{i}}+\sum_{i=0}^{p} \beta_{2} \Delta \mathrm{Labor}_{\mathrm{t}-\mathrm{i}}+\sum_{i=0}^{p} \beta_{3} \Delta \mathrm{Land}_{\mathrm{t}-\mathrm{i}}+\sum_{i=0}^{p} \beta_{4} \Delta \mathrm{Cap}_{\mathrm{t}-\mathrm{i}} \\
& +\sum_{i=0}^{p} \beta_{5} \Delta \mathrm{Fdev}_{\mathrm{t}-\mathrm{i}}+\text { ? }_{1} \mathrm{PO}_{\mathrm{t}-1}+\text { ? }_{2} \mathrm{Labor}_{\mathrm{t}-1}+\text { ? }_{3} \mathrm{Land}_{\mathrm{t}-1}+\text { ? }_{4} \mathrm{Cap}_{\mathrm{t}-1} \\
& + \text { ? }_{5} \mathrm{Fdev}_{\mathrm{t}-1}+\mu_{\mathrm{t}}
\end{aligned}
$$

where $\Delta$ denotes the first difference operator, $\alpha_{0}$ is the drift component, $\varepsilon_{\mathrm{t}}$ is the white noise residuals, and the variables PO, Labor, Land, Cap, and Fdev are as defined earlier. Eq. (4) is a standard VAR model in which a linear combination of lagged-level variables is added as a proxy

\footnotetext{
1 Masih and Masih (1999) argue that although the presence of cointegration should be taken for granted, the justification of rejection of cointegration is necessary due to destabilizing forces, structural breaks, and missing of relevant theoretically inferred variables. Also, it rules out the likely of the spurious relationship between variables.
} 
for lagged error terms which measures the departure of the dependent variable from the independent variables in Eq. (2).

We began the procedure by computing the bound F-statistic to determine the joint significance of variables in a model. The null hypothesis of no long-run relationship between the variables is $\mathrm{H}_{0}$ : ? $?_{1}=?_{2}=?_{3}=?_{4}=?_{5}=0$ against the alternative hypothesis of cointegration $\mathrm{H}_{1}$ $: ?_{1} \neq ?_{2} \neq ?_{3} \neq ?_{4} \neq ?_{5} \neq 0$.. Pesaran et al. (2001) suggest two sets of asymptotic critical values for the F-test. One set assumes that all the variables are $\mathrm{I}(0)$ and another assumes they all are $\mathrm{I}(1)$. The null hypothesis of no cointegration among the variables is rejected if the F-value is higher than the upper bound of the critical values. We also perform the diagnostic tests to check for normality of error term, serial correlation, autoregressive conditional heteroskedasticity, white heteroskedasticity and the functional form of the empirical model.

\section{Results and Discussion}

Table 1 reports summary statistics for all variables used in this study.

Table 1. Descriptive Statistics

\begin{tabular}{llrrrr}
\hline Variable & Unit of measurement & \multicolumn{1}{c}{ Mean } & \multicolumn{1}{c}{ Min } & Max & Std. Dev. \\
\hline Palm Oil Production & Tonne & $11,100,000$ & $2,822,144$ & $20,000,000$ & $5,829,768$ \\
Capital & \% of GDP & 28.260 & 17.836 & 43.640 & 6.942 \\
Labour & Number of employees & 266,896 & 95,237 & 509,831 & 143,826 \\
Land Area & Hectare & $3,287,004$ & $1,121,181$ & $5,811,145$ & $1,473,478$ \\
Private Sector Credit & \% of GDP & 108.346 & 57.761 & 158.505 & 24.881 \\
Stock Trade & \% of GDP & 31.578 & 4.214 & 79.898 & 17.886 \\
Lending-to-deposit spread & $\%$ & 0.551 & 0.080 & 6.010 & 1.386 \\
Bank Branches & Number of branches & 11,551 & 10,510 & 14,050 & 0,940 \\
Non-performing loan-to- & $\%$ & 3.780 & 1.550 & 9.390 & 2.730 \\
gross loans & & & & \\
\hline
\end{tabular}

Table 2. Unit Root Test

\begin{tabular}{|c|c|c|c|c|}
\hline \multirow{3}{*}{ Variables } & \multicolumn{4}{|c|}{ ADF (SIC) } \\
\hline & \multicolumn{2}{|c|}{ Level } & \multicolumn{2}{|c|}{ First Difference } \\
\hline & Constant & $\begin{array}{c}\text { Constant \& } \\
\text { Trend }\end{array}$ & Constant & Constant \& Trend \\
\hline L(Palm Oil Production) (PO) & $-8.991 * * *$ & $-10.546^{* * *}$ & $-10.208^{* * *}$ & $-10.029 * * *$ \\
\hline LCapital & -1.808 & -1.936 & $-5.318^{* * *}$ & $-5.252 * * *$ \\
\hline LLabor & -0.820 & -1.062 & $-5.046^{* * *}$ & $-5.086 * * *$ \\
\hline LArea & $-3.888 * * *$ & -0.852 & $-4.361 * * *$ & $-6.037 * * *$ \\
\hline LPrivate Sector Credit & -1.428 & -2.260 & $-5.407 * * *$ & $-4.855^{* * *}$ \\
\hline LStock Trade & -2.332 & $-3.869 * *$ & $-6.423 * * *$ & $-6.554 * * *$ \\
\hline LLending-to-deposit spread & -2.051 & -2.064 & $-3.364 * * *$ & $-3.430 *$ \\
\hline LBank Branches & -1.880 & -0.913 & -1.516 & -2.252 \\
\hline LNon-performing loan-to-gross loans & -2.469 & 0.161 & -1.726 & $-3.985^{* *}$ \\
\hline
\end{tabular}

Note: $*, * *, * * *$ are significant at the $10 \%, 5 \%$, and $1 \%$, respectively. $\mathrm{H}_{0}$ assumes that series are non-stationary or contains a unit root.

The following results report the ARDL procedural techniques. Table 2 presents the results obtained from the ADF unit root test based on the Schwarz Information Criterion (SIC). It suggests that some of the variables (palm oil production, land, and stock trade) are stationary at the level form and all variables become stationary at first difference i.e. I (1). Therefore, the application of ARDL model is justified. 
Table 3 shows the estimated F-statistics for analyzing the existence of a long-run palm oil productivity equation. The null hypothesis is that no long-run relationship exists among the regressors. We compare the F-values with the critical bounds provided in (Narayan \& Narayan, 2004). Since the estimated F-values of all palm oil productivity models (M1-M5) is greater than the upper bound of the critical values, it shows the existence of cointegration between palm oil production and its determinants.

Table 3. Bounds Cointegration Test

\begin{tabular}{|c|c|c|c|c|c|c|c|}
\hline \multicolumn{8}{|c|}{ Critical values for the bound test: restricted and no trend } \\
\hline \multirow[t]{2}{*}{$\mathrm{N}$} & \multirow[t]{2}{*}{$\mathrm{k}$} & \multicolumn{2}{|c|}{$90 \%$ level } & \multicolumn{2}{|c|}{$95 \%$ level } & \multicolumn{2}{|c|}{$99 \%$ level } \\
\hline & & $\mathrm{I}(0)$ & $\mathrm{I}(1)$ & $\mathrm{I}(0)$ & $\mathrm{I}(1)$ & $\mathrm{I}(0)$ & $\mathrm{I}(1)$ \\
\hline 31 & 4 & 2.518 & 3.513 & 3.033 & 4.188 & 4.320 & 5.785 \\
\hline 37 & 4 & 2.458 & 3.432 & 2.928 & 4.042 & 4.030 & 5.463 \\
\hline \multicolumn{6}{|c|}{ Model } & \multicolumn{2}{|c|}{ F- Statistic } \\
\hline \multicolumn{6}{|c|}{ M1) F(PO I Capital, Labor, Area, Private Sector Credit) } & \multicolumn{2}{|c|}{$6.688^{* * *}$} \\
\hline \multicolumn{6}{|c|}{ M2) F(PO I Capital, Labor, Area, Stock Trade) } & \multicolumn{2}{|c|}{$8.749 * * *$} \\
\hline \multicolumn{6}{|c|}{ M3) F(PO I Capital, Labor, Area, Lending-to-Deposit Spread) } & \multicolumn{2}{|c|}{$20.073^{* * *}$} \\
\hline \multicolumn{6}{|c|}{ M4) F(PO I Capital, Labor, Area, Bank Branches) } & \multicolumn{2}{|c|}{$5.699 * * *$} \\
\hline \multicolumn{6}{|c|}{ M5) F(PO I Capital Labor Area Non-performing Loan-to-Gross Loan) } & \multicolumn{2}{|c|}{$6.281 * * *$} \\
\hline
\end{tabular}

Table 4 provides the level of long-run parameter estimates of the five models. We found mix results across the models. The findings indicate that financial depth (private sector credit and stock trade) has a positive long-run relationship with palm oil production (see M1 and M2). It shows that a 1 percent increase in private sector credit and stock trade will increase palm oil production by 0.11 percent and 0.06 percent, respectively. Whereas capital, labor, and land have negative effects on palm oil production. The results for M1 show that a 1 percent increase in labor and land will decrease palm oil production by 0.14 percent and 0.30 percent, respectively. Meanwhile, a 1 percent increase in capital will reduce palm oil production by 0.13 percent (see M2). These results for M1 and M2 could be based on the argument given by Stijepic (2017) who provides empirical evidence regarding the adequacy of the CDFPs in the multi-sector study, suggesting that labor-income share and capital intensity might differ across sectors.

Table 4. Long Run ARDL Results

\begin{tabular}{llllcc}
\hline \multicolumn{1}{c}{ Variables } & \multicolumn{1}{c}{ M1 } & \multicolumn{1}{c}{ M2 } & \multicolumn{1}{c}{ M3 } & M4 & M5 \\
\hline Constant & $2.257^{* * *}$ & $2.123^{* * *}$ & $4.064^{* * *}$ & $5.696^{* *}$ & 6.609 \\
Capital & -0.003 & $-0.121^{* * *}$ & -0.109 & -0.071 & -0.023 \\
Labor & $-0.142^{* * *}$ & $-0.098^{* *}$ & -0.075 & -0.082 & $-0.192^{*}$ \\
Area & $-0.295^{* * *}$ & -0.042 & -0.112 & -0.178 & -0.196 \\
Private Sector Credit & $0.109^{* * *}$ & & & & \\
Stock Trade & & $0.058^{* * *}$ & & & \\
Lending-to-deposit spread & & & -0.010 & & -0.255 \\
Bank Branches & & & & & -0.028 \\
Non-performing loan-to-gross loans & & & &
\end{tabular}

Nevertheless, for other financial development measures, the study found no significant evidence on the impact of financial access (bank branches), efficiency (lending-deposit spread) 
and stability (non-performing loan-to-gross loan) on palm oil production (see M3-M5). The findings contradict previous studies that evidence a positive relationship between finance and agricultural production (such as Rahman et al., 2014; Sandip et al., 2015; Shahbaz et al., 2013). The results could be explained by the small series of data involving the three variables (19962017), which fail to capture the long run finance-palm oil production relationship.

Results obtained from the analysis support the idea that previously proposed by Alexander (1952) and Bahmani-Oskooee (1997). According to their studies, the inflationary effects of the exchange rate increase redistribute income from workers to producers. In Turkey, wages are determined by collective agreements. Exchange rate increases directly cause a cost in inflation but because of the agreements, nominal wages cannot be immediately adjusted to the price increases. Results obtained from our work also support previous empirical works done by Shahbaz, Islam, and Butt (2011) and Bahmani-Oskooee and Motavallizadeh-Ardakani (2018). Similar to the results of our study, previous studies have concluded that the increase in the exchange rate leads to more unequal income distribution.

Table 5. OLS Results for Model 3-5

\begin{tabular}{llll}
\hline Variables & M3 & M4 & M5 \\
\hline Constant & 3.232 & $8.540^{*}$ & $20.35^{* *}$ \\
Capital & 0.035 & -0.033 & -0.121 \\
Labor & $8.290^{* *}$ & 5.8800 & -0.002 \\
Area & $0.840^{* * *}$ & $0.602^{* *}$ & -0.198 \\
Lending-to-deposit spread & -0.024 & & \\
Bank Branches & & -0.426 & \\
Non-performing loan-to-gross loans & & & $-0.174^{*}$ \\
\hline $\mathrm{R}^{2}$ & 0.952 & 0.843 & 0.815 \\
$\mathrm{X}^{2}$ Auto & 0.110 & 0.894 & $3.969^{*}$ \\
$\mathrm{X}^{2}$ White & 0.331 & 1.540 & 0.000 \\
$\mathrm{X}^{2}$ RESET & $2.506^{*}$ & 0.532 & 0.121 \\
\hline
\end{tabular}

Table 6. Short Run ARDL Results

\begin{tabular}{|c|c|c|c|c|c|}
\hline Variable & M1 & M2 & M3 & M4 & M5 \\
\hline $\mathrm{D}(\mathrm{PO})$ & $3.335 * * *$ & $1.251 * * *$ & $2.257 * * *$ & $2.123^{* * *}$ & $1.426^{* * *}$ \\
\hline $\mathrm{D}$ (Capital) & 0.112 & $-0.199 *$ & -0.183 & -0.593 & -0.292 \\
\hline $\mathrm{D}$ (Labor) & 0.147 & -0.195 & -0.126 & -0.195 & $-0.414 *$ \\
\hline $\mathrm{D}$ (Area) & $-1.482 * *$ & 0.042 & -0.188 & -1.456 & -0.423 \\
\hline D(Private Sector Credit) & -0.148 & & & & \\
\hline $\mathrm{D}$ (Stock Trade) & & $0.062^{*}$ & & & \\
\hline $\mathrm{D}$ (Lending-to-deposit spread) & & & 0.021 & & \\
\hline D(Bank Branches) & & & & -0.606 & \\
\hline $\mathrm{D}$ (Non-performing loan-to-gross loans) & & & & & $-0.568^{*}$ \\
\hline $\mathrm{ECM}_{\mathrm{t}-1}$ & $-6.091 * * *$ & $-2.985^{* * *}$ & $-1.684 * * *$ & $-2.373 * *$ & $-2.159 * *$ \\
\hline $\mathrm{R}^{2}$ & 0.9931 & 0.995 & 0.577 & 0.597 & 0.612 \\
\hline $\mathrm{X}^{2}$ Auto & 1.863 & 1.255 & 1.695 & 2.113 & 0.016 \\
\hline $\mathrm{X}^{2}$ Norm & 2.741 & 1.387 & 1.108 & 0.636 & 0.153 \\
\hline $\mathrm{X}^{2}$ White & 0.745 & 1.689 & 0.158 & 0.038 & 0.148 \\
\hline $\mathrm{X}^{2} \mathrm{RESET}$ & 1.709 & 0.871 & 1.910 & 0.975 & 1.621 \\
\hline
\end{tabular}

Notes: 1$)^{*}, * *, * * *$ are significant at the $10 \%, 5 \%$, and $1 \%$, respectively.
2) $\mathrm{X}^{2}$ Auto is the Breusch-Godfrey LM test for autocorrelation.
3) $\mathrm{X}^{2}$ Norm is the Jarque-Bera normality test.
4) $X^{2}$ White is the White test for heteroscedasticity.
5) $\mathrm{X}^{2} \mathrm{RESET}$ is the Ramsey test for omitted variables/functional. 
The study conducted further analysis by using OLS models as reported in Table 5. The findings suggest that only financial stability has a significant and negative impact on palm oil production. This negative results associated with non-performing loans could be accrued to the effects of credit access on business efficiency (Aghion et al., 2018) and also on credit risk and asset quality (Chen et al., 2018). Results for model 3 and 5, however, shows the existence of model specification and autocorrelation problems, respectively.

In the short run, the findings in Table 6 indicate that stock trade has a positive effect while bank branches have a negative effect on palm oil production. The negative effect of bank branches is expected considering the current trend of financial technology that in favor of online financial services compared to over-the-counter services. The estimated lagged error correction term $\left(\mathrm{ECM}_{\mathrm{t}-1}\right)$ in all models are found to be significantly negative. The negative estimates suggest the speed of adjustment from the short run to long run. For instance, the estimated $\mathrm{ECM}_{\mathrm{t}-1}$ in M1 indicates that the short-run deviation towards long run is corrected by 6.09 percent per year.

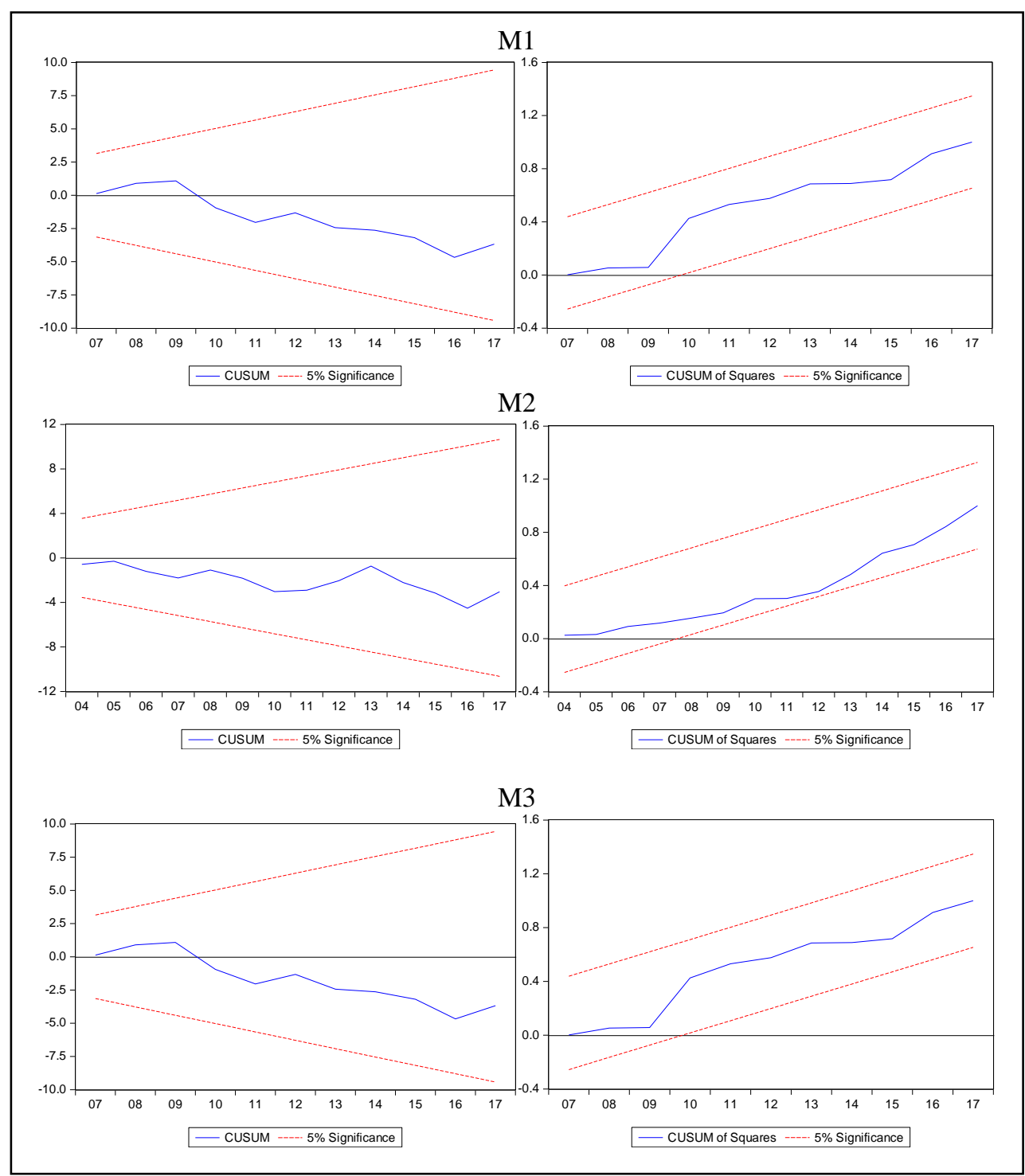




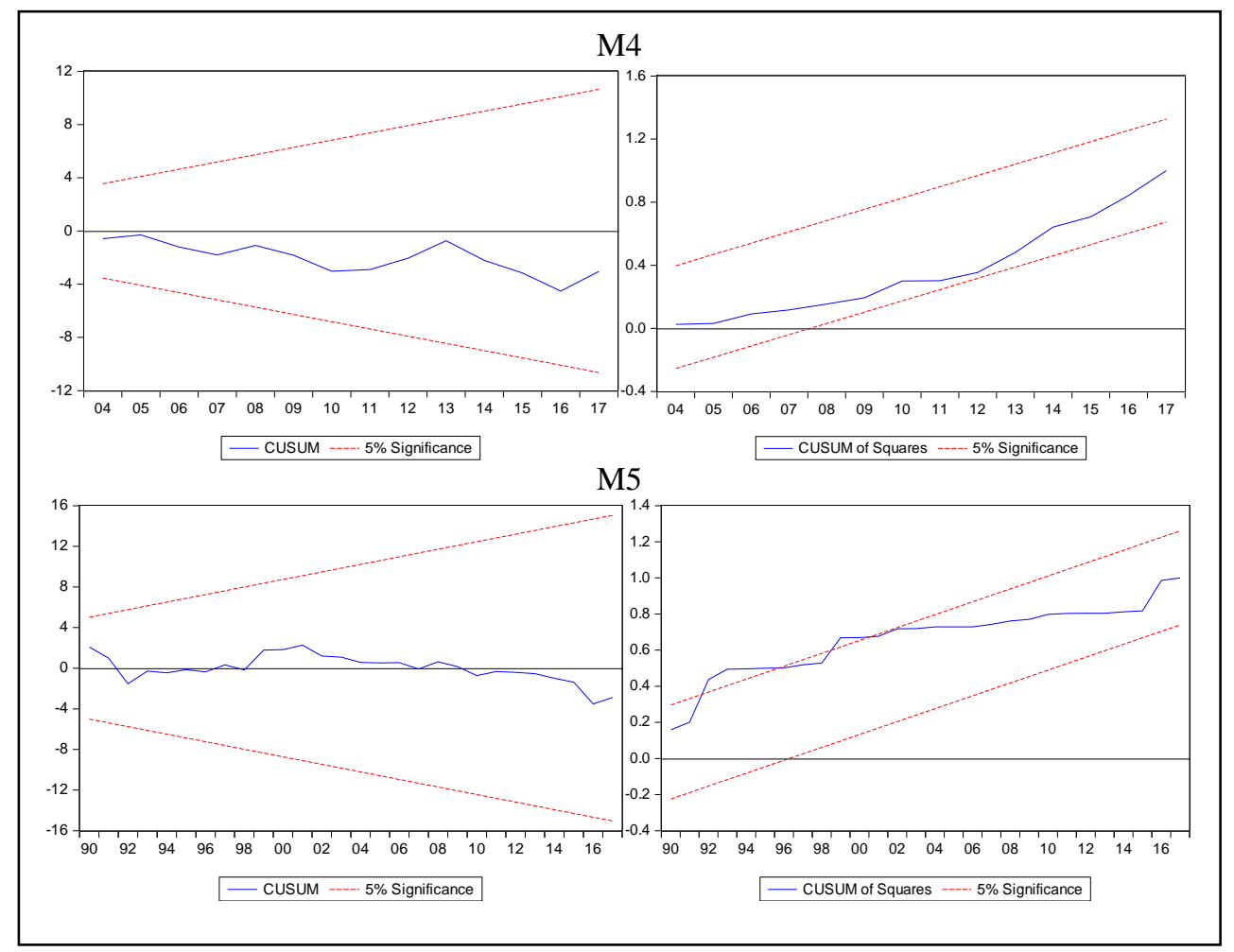

Figure 1. CUSUM and CUSUMsq

Based on the diagnostic test results, all models are free from the problems of autocorrelation, non-normality of residuals, serial correlation, autoregressive conditional heteroskedasticity, white heteroskedasticity, and the model misspecification. Following Hansen (1992), the stability test statistic is conducted using CUSUM and CUSUMsq tests as depicted in Figure 1. It shows that the ARDL parameters are found to be stable as most of the graphs of the CUSUM and CUSUMsq (blue lines) are within critical bounds at a 5 percent level of significance.

\section{Conclusion}

This study aims to examine the relationship between financial development and palm oil industry production in Malaysia from 1981 to 2017. Based on the ARDL testing approach, the findings show that the depth of the financial market has a positive impact on palm oil industry performance both in the short run and long run, though the depth of the financial institutions only takes effect in the long run. For other financial development indicators (i.e., financial accessibility, efficiency, and stability), the results show that they have no significant effect on the productivity of the industry. The findings imply that equity market development is more relevant to affect the palm oil industry in Malaysia compared to credit market development. These unique findings will furnish the policymakers with relevant information related to the palm oil industry and earmark the need to prioritize financial system development that in turn, helps to realize the long-term economic growth of Malaysia agriculture in general, and palm oil industry in particular.

\section{Acknowledgments}

The authors appreciate the valuable comments by the anonymous reviewers and the financial support from the Malaysia Palm Oil Research grant (code: EP-2017-058). 


\section{References}

Aghion, P., Bergeaud, A., Cette, G., Lecat, R., \& Maghin, H. (2018). The inverted-U relationship between credit access and productivity growth (Banque de France Working Paper No. 696). Retrieved from https://scholar.harvard.edu/files/aghion/files/invertedu_relationship.pdf

Ahmed, A. D. (2006). The impact of financial liberalization policies: The case of Botswana. Journal of African Development, 1(7), 13-38. Retrieved from http://www.afeawpapers.org/RePEc/afe/afe-journl/wpcontent/uploads/2014/07/JAD_vol8_Chapter1.pdf

Alexander, S. S. (1952). Effects of a devaluation on a trade balance. Staff Papers, 2(2), 263-278.

Asari, F. F. A. H., Rahman, N. H. A., Razak, E. A. A., Ahmad, B. A. S., Harun, N. F. A., \& Jusoff, K. (2011). A time series analysis of the relationship between total area planted, palm oil price and production of Malaysian palm oil. World Applied Sciences Journal, 12(Special Issue on Bolstering Economic Sustainability), 34-40. Retrieved from https://pdfs.semanticscholar.org/f229/5313325eed8349e43a3692199f04f653338.pdf

Ayat, K. A. R., Ramli, A., \& Faizah, M. S. (2012). The economic impact of the North-east monsoon and La Nina on production in Malaysia. Oil Palm Industry Economic Journal, 12(22-35). Retrieved from http://palmoilis.mpob.gov.my/publications/OPIEJ/opiejv12n2-ayat.pdf

Ayaz, S., \& Hussain, Z. (2011). Impact of institutional credit on production efficiency of farming sector: A case study of District Faisalabad. Pakistan Economic and Social Review, 49(2), 149162. Retrieved from http://www.jstor.org/stable/23622108

Bahmani-Oskooee, M. (1997). Effects of devaluation on income distribution. Applied Economics Letters, 4(5), 321-323.

Bahmani-Oskooee, M., \& Motavallizadeh-Ardakani, A. (2018). Exchange rate changes and income distribution in 41 countries: Asymmetry analysis. 68, Quarterly Review of Economics and Finance, 68(C), 266-282. https://doi.org/10.1016/j.qref.2017.11.009

Banerjee, A., Dolado, J., \& Mestre, R. (1998). Error-correction mechanism tests for cointegration in a single-equation framework. Journal of Time Series Analysis, 19(3), 267-283. https://doi.org/10.1111/1467-9892.00091

Banerjee, A., Galbraith, J., \& Hendry, D. (1993). Co-integration, error correction, and the econometric analysis of non-stationary data. Oxford: Oxford University Press. https://doi.org/10.1093/0198288107.001.0001

Bashir, M. K., Mehmood, Y., \& Hassan, S. (2010). Impact of Agricultural Credit on Productivity of Wheat Crop: Evidence from Lahore, Punjab, Pakistan. Pakistan Journal of Agricultural Sciences, 47(4), 405-449. Retrieved from https://pakjas.com.pk/papers/68.pdf

Bauer, P. W. (1990). Decomposing TFP growth in the presence of cost inefficiency, nonconstant returns to scale, and technological progress. Journal of Productivity Analysis, 1(4), 287-299. https://doi.org/10.1007/BF00160047

Beck, T., Demirgüç-Kunt, A., \& Levine, R. (2010). Financial institutions and markets across countries and over time. World Bank Economic Review, 24(1), 77-92. https://doi.org/10.1093/wber/lhp016 
Bergmann, D., O’Connor, D., \& Thümmel, A. (2016). An analysis of price and volatility transmission in butter, palm oil and crude oil markets. Agricultural and Food Economics, 4(1), 23. https://doi.org/10.1186/s40100-016-0067-4

Bowers, W. J., \& Pierce, G. (1975). The illusion of deterrence in Isaac Ehrlich's research on capital punishment. Yale Law Journal, 85(2), 187-208.

Box, G. E. P., \& Cox, D. R. (1964). An analysis of transformations. Journal of the Royal Statistical Society, 26(2), 211-243.

Brenes Muñoz, T., Lakner, S., \& Brümmer, B. (2012). Economic growth of farms: An empirical analysis on organic farming. In 28th Triennial Conference of the International Association of Agricultural Economists (LAAE). Foz do Iguaçu, Brazil: International Association of Agricultural Economists. Retrieved from https://ideas.repec.org/s/ags/iaae12.html

Brooks, J. (2016). Food security and the sustainable development goals. In P. Love (Ed.), Debate the issues: New approaches to economic challenges. Organisation for Economic Cooperation and Development (OECD). https://doi.org/10.1787/9789264264687-27-en

Burja, C. (2012). Determinants of the agricultural productivity growth among Romanian regions. Annales Universitatis Apulensis Series Oeconomica, 14(1), 217-225. Retrieved from http://oeconomica.uab.ro/upload/lucrari/1420121/18.pdf

Campos, M., Jaklic, T., \& Juvancic, L. (2010). Factors affecting farm productivity in Bulgaria, Hungary, Poland, Romania and Slovenia after the EU-accession and likely structural impacts. In Paper prepared for presentation at the 118th EAAE Seminar "Rural development: Governance, policy design and delivery" (pp. 939-952). Ljubliana: (European Association of Agricultural Economists. Retrieved from https://core.ac.uk/download/pdf/6372602.pdf

Chen, F. W., Feng, Y., \& Wang, W. (2018). Impacts of financial inclusion on non-performing loans of commercial banks: Evidence from China. Sustainability (Switzerland), 10(9), 1-28. https://doi.org/10.3390/su10093084

Chisasa, J., \& Makina, D. (2015). Bank credit and agricultural output in south africa: cointegration, short run dynamics and causality. Journal of Applied Business Research (JABR), 31(2), 489-500. https://doi.org/10.19030/jabr.v31i2.9148

Chuangchid, K., Wiboonpongse, A., Sriboonchitta, S., \& Chaiboonsri, C. (2012). Factors affecting palm oil price based on extremes value approach. International Journal of Marketing Studies, 4(6), 54-65. https://doi.org/10.5539/ijms.v4n6p54

Cihak, M., Demirguc-Kunt, A., Feyen, E., \& Levine, R. (2012). Benchmarking financial systems around the world. Policy Research Working Papers. The World Bank. https://doi.org/10.1596/18139450-6175

Demirgüç-Kunt, A., \& Levine, R. (2008). Finance, financial sector policies, and long-run growth commission on growth and development (Working Paper No. 11). Washington. https://doi.org/10.1596/1813-9450-4469

Devi, R. U. (2012). Impact of co-operative loan on agricultural sector: A case study of E.G. district Andhra Pradesh. Journal of Arts, Science and Commerce, 4(2), 74-84. Retrieved from http://www.researchersworld.com/vol3/issue4/vol3_issue4_2/Paper_10.pdf

Dong, F., Jing, L., \& Featherstone, A. M. (2010). Effects of credit constraints on productivity and rural bousehold income in China (Working Paper 10-WP No. 516). Retrieved from 
https://pdfs.semanticscholar.org/3a27/773371012b8a3c0d2f38e78c3289e3a6a2e2.pdf

Duy, V. (2012). The role of access to credit in rice production efficiency of rural housebolds in the Mekong Delta, Vietnam (CAS Discussion Paper No. 84) (Vol. cimda). Retrieved from https://www.researchgate.net/publication/236271986_The_role_of_access_to_credit_in _rice_production_efficiency_of_rural_households_in_the_Mekong_Delta_Vietnam

Engle, R. F., \& Granger, C. W. (1987). Co-integration and error correction: Representation, estimation, and testing. Econometrica: Journal of the Econometric Society, 55(2), 251-276.

ETP. (2012). Annual report - Prime Minister's Office of Malaysia. Retrieved from https://www.pmo.gov.my/dokumenattached/Eng_ETP2012_Full.pdf

Gokmenoglu, K. K., Amin, M. Y., \& Taspinar, N. (2015). The relationship among international trade, financial development and economic growth: The case of Pakistan. Procedia Economics and Finance, 25, 489 - 496. https://doi.org/10.1016/S2212-5671(15)00761-3

Hannig, A., \& Jansen, S. (2010). Financial inclusion and financial stability: Current policy issues (ADBI Working Paper No. 259). Tokyo.

Hansen, B. E. (1992). Testing for parameter instability in linear Models. Journal of Policy Modeling, 14(4), 517-533. https://doi.org/10.1016/0161-8938(92)90019-9

Harangus, D. (2009). Banking products for agriculture in digital economy. Bulletin UASVM Horticulture, 66(22), 232-236. Retrieved from http://journals.usamvcluj.ro/index.php/horticulture/article/viewFile/4343/4035

Hsueh, S.-J., Hu, Y.-H., \& Tu, C.-H. (2013). Economic growth and financial development in Asian countries: A bootstrap panel Granger causality analysis. Economic Modelling, 32(C), 294-301. https://doi.org/10.1016/j.econmod.2013.02,

Hussain, F., \& Chakraborty, D. K. (2012). Causality between financial development and economic growth: Evidence from an Indian State. Romanian Economic Journal, 15(35), $27-$ 48. Retrieved from

http://www.rejournal.eu/sites/rejournal.versatech.ro/files/articole/2012-0901/2003/hussain.pdf

Hye, Q. M. A., \& Wizarat, S. (2011). Financial liberalization and services sector growth: Empirical evidence from Pakistan. IUP Journal of Applied Finance, 17(2), 16-24.

Ibrahim, A. H., \& Bauer, S. (2013). Access to microfinance and its impact on farm profits among rural farmers in Dryland of Sudan. Global Advanced Research Journal of Agricultural Sciences, 2(3), 88-102.

Iqbal, M., Ahmad, M., \& Abbas, K. (2003). The impact of institutional credit on agricultural production in Pakistan. The Pakistan Development Review, 42(4), 469-485. Retrieved from http://www.pide.org.pk/pdf/PDR/2003/Volume4/469-485.pdf

Izhar, A., \& Tariq, M. (2009). Impact of institutional credit on aggregate agricultural production in India during post reform period (MPRA Paper No. 17075). Retrieved from http:/ / mpra.ub.unimuenchen.de/17075/

Jan, I., \& Khan, H. (2012). Factors responsible for rural household participation in institutional credit programs in Pakistan. African Journal of Business Management, 6(3), 1186-1190. 
Johansen, S. (1988). Statistical analysis of cointegration vectors. Journal of Economic Dynamics and Control, 12(2), 231-254. https://doi.org/10.1016/0165-1889(88)90041-3

Johansen, S. (1995). Likelihood-based inference in cointegrated vector autoregressive models. Oxford: Oxford University Press. https://doi.org/10.1093/0198774508.001.0001

Johansen, S., \& Juselius, K. (1990). Maximum likelihood estimation and inference on cointegration - with applications to the demand for money. Oxford Bulletin of Economics and Statistics, 52(2), 169-210. https://doi.org/10.1111/j.1468-0084.1990.mp52002003.x

King, R. G., \& Levine, R. (1993a). Finance, entrepreneurship and growth. Journal of Monetary Economics, 32(3), 513-542. https://doi.org/10.1016/0304-3932(93)90028-E

King, R. G., \& Levine, R. (1993b). Finance and growth: Schumpeter might be right. The Quarterly Journal of Economics, 108, 717-737. https://doi.org/10.2307/2118406

Levine, R. (1997). Financial Development and Economic Growth: Views and Agenda. Journal of Economic Literature, 35(2), 688-726.

Levine, R. (2005). Finance and growth: Theory and evidence. In Philippe Aghion \& S. Durlauf (Eds.), Handbook of Economic Growth (1st ed., pp. 865-934). Amsterdam: Elsevier.

Masih, A. M. M., \& Masih, R. (1999). Are Asian stock market fluctuations due mainly to intraregional contagion effects? Evidence based on Asian emerging stock markets. Pacific-Basin Finance Journal, 7, 251-282. https://doi.org/10.1016/S0927-538X(99)00013-X

McKinnon, R. (1973). Money and capital in economic development. Washington DC: Brookings Institution Press.

Ministry of Finance Malaysia. (2017). Economic Report 2016/2017. Retrieved from https://www.treasury.gov.my/index.php/en/archives/2017/economic-report

MPOB. (2017). Economic and Industry Division. Retrieved from http://bepi.mpob.gov.my/index.php/en/

Muftau, A. I. (2003). Commercial bank credit to the agricultural sector and the Nigerian economy: An analysis of the future trend. Advances in Management, 3(1), 86-94.

Narayan, S., \& Narayan, P. K. (2004). An export demand model for Fiji (Developing Economies No. XLII).

Nazlioglu, S., \& Soytas, U. (2012). Oil price, agricultural commodity prices, and the dollar: A panel cointegration and causality analysis. Energy Economics, 34(4), 1098-1104. Retrieved from https://econpapers.repec.org/RePEc:eee:eneeco:v:34:y:2012:i:4:p:1098-1104

Nosiru, M. O. (2010). Microcredits and agricultural productivity in Ogun State, Nigeria. World Journal of Agricultural Sciences, 6(3), 290-296. Retrieved from https://pdfs.semanticscholar.org/08d1/7a69b3b1d383134f517bb616be6cadf171c0.pdf

Nuryartono, N., Pasaribu, S. H., \& Panggabean, P. N. K. (2016). Total factor productivity analysis of oil palm production in Indonesia. International Journal of Economics and Financial Issues, 6(4), 1570-1577. Retrieved from https://www.econjournals.com/index.php/ijefi/article/view/2866/pdf

Obilor, S. I. (2013). The impact of commercial banks' credit to agriculture on agricultural development in Nigeria: An econometric analysis. International Journal of Business, Humanities 
and Technology, 3(1), 85-94. Retrieved from https://www.ijbhtnet.com/journals/Vol_3_No_1_January_2013/11.pdf

Odhiambo, N. M. (2010). Finance-investment-growth nexus in South Africa: An ARDL-bounds testing procedure. Economic Change and Restructuring, 43(3), 205-219. https://doi.org/10.1007/s10644-010-9085-5

OECD-FAO. (2017). Southeast Asia: Prospects and challenges. In Agricultural outlook 2017-2026. Retrieved from http://www.fao.org/3/a-bt099e.pdf

Olagunju, F. I. (2008). Economics of palm oil processing in Southwestern Nigeria. International Journal of Agricultural Economics and Rural Development, 1(2), 69-77. Retrieved from http://dirae.lunarservers.com/ laute0/journal/ijaerd2/ijaerd-2.9.pdf

Oliynyk, O. (2017). Financial system and agricultural growth in Ukraine. Organizacija, 50(3), 244 254. https://doi.org/10.1515/orga-2017-0016

Omri, A., Daly, S., Rault, C., \& Chaibi, A. (2015). Financial development, environmental quality, trade and economic growth: What causes what in MENA countries. Energy Economics, 48(C), 242-252. Retrieved from https://econpapers.repec.org/RePEc:eee:eneeco:v:48:y:2015:i:c:p:242-252

Pesaran, M. H., Shin, Y., \& Smith, R. J. (2001). Bounds testing approaches to the analysis of level relationships. Journal of Applied Econometrics, 16(3), 289-326. https://doi.org/10.1002/jae.616

Rachdi, H., \& Mbarek, H. B. (2011). The causality between financial development and economic growth: Panel Data Co-integration and GMM system approaches. International Journal of Economics and Finance, 3(1), 143-151.

Rahman, S. U., Hussain, A., \& Taqi, M. (2014). Impact of agricultural credit on agricultural productivity in Pakistan: An empirical analysis. International Journal of Advanced Research in Management and Social Sciences, 3(4).

Rajan, R. G., \& Zingales, L. (1998). Financial dependence and growth. The American Economic Review, 88(3), 559-586. Retrieved from http://www.jstor.org/stable/116849

Ramasamy, B., Ong, D., \& Yeung, M. C. (2005). Firm size, ownership and performance in the Malaysian palm oil industry. Asian Academy of Management Journal of Accounting and Finance, $1,181-104$.

Robinson, J. (1952). The generalisation of the general theory, in the rate of interest and other essays (2nd ed.). London, UK.: MacMillan Publishing Company.

Sandip, S., Kumar, G. S., \& Mollika, P. (2015). Role of banking-sector to inclusive growth through inclusive finance in Bangladesh. Studies in Business and Economics, 10(2).

Schumpeter, J. (1911). The theory of economic development: An inquiry into profits, capital, credit, interest and the business cycle. Cambridge: Harvard University Press.

Shahbaz, M., Islam, F., \& Butt, M. S. (2011). Devaluation and income inequality: Evidence from Pakistan (MPRA Paper No. 35522). Retrieved from http://mpra.ub.uni-muenchen.de/35522/

Shahbaz, M., Shabbir, M. S., \& Sabihuddin, B. M. (2013). Effect of financial development on agricultural growth in Pakistan: New extensions from bounds test to level relationships 
and Granger causality tests. International Journal of Social Economics, 4(9), 707-728.

Shaw, E. S. (1973). Financial deepening in economic development. New York: Oxford University Press.

Simwaka, K., Ligoya, P., Kabango, G., \& Chikonda, M. (2012). Money supply and inflation in Malawi: An econometric investigation. Journal of Economics and International Finance, 4(2), 36.

Solow, R. M. (1997). Is there a core of usable macroeconomics we should all believe In? American Economic Review, 87(2), 230-232.

Stijepic, D. (2017). An argument against Cobb-Douglas production functions (in multi-sectorgrowth modeling). Economics Bulletin, AccessEcon, 37(2), 1143-1150. Retrieved from https://ideas.repec.org/a/ebl/ecbull/eb-17-00103.html

Toby, A. J., \& Peterside, D. B. (2014). Analysis of the role of banks in financing the agriculture and manufacturing sectors in Nigeria. International Journal of Research in Business Management, 2(2), 9-22.

United Plantation. (2016). Annual Report 2016. 